\title{
Options appraisal of waste management systems
}

\author{
T. C. Clifford \\ Arup, UK
}

\begin{abstract}
Based on a real case study this paper will set out a methodology for appraising different waste management solutions using cost benefit and multi-criteria analysis to shortlist the most appropriate solutions. The paper will also describe a MS Excel based model used to calculate and compare net cashflow for each shortlisted option.

The paper will provide a step by step guide to options appraisal and the selection of the preferred solution using real data. The results will demonstrate how the mix of recycling, energy recovery and residual waste disposal, the technology choice and maximising electricity or energy output all impact of the ranking of the options.

For the case study the ranking results will set out the conclusion from this particular options appraisal, which will be explored with regard to key sensitivities to illustrate the most significant factors in the options appraisal process.
\end{abstract}

Keywords: waste, waste management, options appraisal, forecast, scenario, cashflow, case study, model, spreadsheet, sensitivity analysis.

\section{Introduction}

This paper sets out a process for the appraisal of different waste management options and is based on a real case study from the Middle East. The process uses a number of different techniques and spreadsheet based models to assist with the identification of the preferred option for these particular circumstances. 


\section{Waste forecasting model}

The first stage of the process is to estimate the waste arisings and their composition using the Waste Forecasting Model. The forecast horizon is agreed and for the case study this was 25 years. The assumptions to be used in the model are then developed and determined. These include waste generation rates; gross to net floor area ratios and occupancy rate.

The waste generation rates used are either per capita or floor area derived with one or two exceptions such as restaurants, for which a per cover ratio is used. Default waste generation rates are taken from BS 5906 (2005) (British Standards Institute [1]) but wherever possible these default rates are substituted with relevant empirical data. The estimated amount of waste is forecast as the product of the waste generation rate and population or floor area.

Gross to Net Floor Area ratios are important to the accuracy of the Waste Forecast Model - with regard to floor area based waste estimates - as these account for interior walls and similar structures which reduce the available floor area and hence waste arisings. This ratio can be expressed as a decimal fraction or percentage the e.g. 0.8 or $80 \%$.

Occupancy rates are also used to improve the accuracy of the Waste Forecasting Model. For example an office block may never be fully occupied. The Waste Forecasting Tool initially estimates waste arisings the basis of $100 \%$ occupation but by including an estimation of the actual Occupancy Rate, say $95 \%$, a more accurate estimation of the waste arisings is possible.

The forecast horizon is not static and by using time related data regarding the build out of particular developments and/or demographic information in relation to population trends the forecast horizon can be profiled to show waste arisings over time with the final output being presented as a histogram as show in Figure 1.

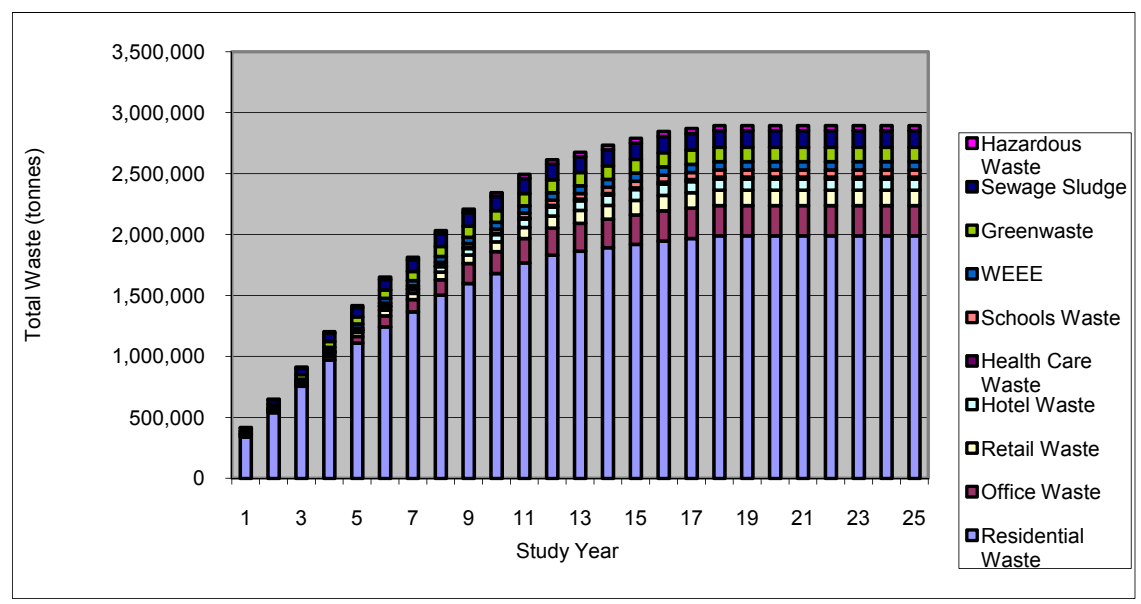

Figure 1: Waste forecast ouput. 
Waste composition data for the municipal waste stream derived from research sources or from actual waste composition studies can then be applied to the profiled waste arisings to determine the estimated quantity of each waste fraction. This data is then used in scenario development.

\section{Scenario development}

For the case study the approach to scenario development was based on moving from the business as usual (landfill) position towards, as far as possible, a zero waste to landfill position.

This process is initially workshop driven producing a series of scenarios with differing mixes of materials recycling, energy recovery and landfill. The initial scenarios are then subject to mass balance calculations using the waste forecast

Table 1: $\quad$ Estimated waste fraction quantities.

\begin{tabular}{|c|c|c|c|c|c|}
\hline Materials Recovery & & Study Year 1 & 2 & 3 & 4 \\
\hline Glass & tonnes per annum & 4,681 & 7,255 & 10,165 & 13,511 \\
\hline $\begin{array}{c}\text { Paper } \\
\text { Cardboard }\end{array}$ & tonnes per annum & 35,056 & 53,803 & 75,284 & 101,441 \\
\hline Plastic & tonnes per annum & 25,392 & 39,964 & 56,099 & 72,858 \\
\hline Metal & tonnes per annum & 8,987 & 13,929 & 19,522 & 25,966 \\
\hline WEEE & tonnes per annum & 1,996 & 3,115 & 4,370 & 5,753 \\
\hline Total Recovery & tonnes per annum & 76,111 & 118,066 & 165,440 & 219,529 \\
\hline
\end{tabular}

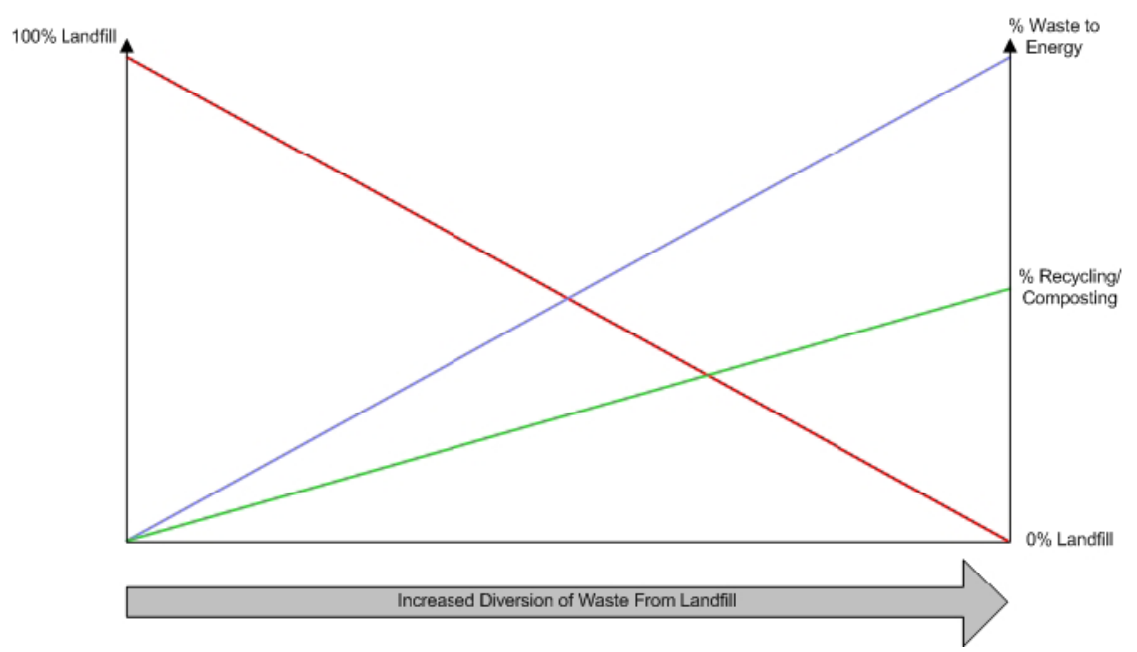

Figure 2: $\quad$ Scenario development. 
data to ensure that the waste composition and estimated tonnages are sufficient for each 'mix'. In the case study this process produced eight options plus the base case - 'Business as Usual' and indicated that under valid mass balance conditions it was also necessary to include anaerobic composting to achieve high levels of recycling.

At this stage a high level cost benefit analysis can be undertaken to identify those scenarios, excluding the Business as Usual case, for which detailed options appraisal will be undertaken. For the case study this consisted of gate fee estimates and Global Warming Potential, as calculated using the WRATE tool (Environment Agency [2]). The results from the costing exercise were ranked least expensive (1) to most expensive (8) and for Global Warming Potential (GWP) least impact (1) to highest impact (8). An overall ranking was then determined as a product of the two individual rankings.

Due to limitations within the WRATE tool it was not possible to calculate the GWP impact of plasma gasification.

Table 2: $\quad$ Case study scenarios.

\begin{tabular}{|l|c|c|c|c|}
\hline Scenario & $\begin{array}{c}\text { Recycling } \\
(\%)\end{array}$ & $\begin{array}{c}\text { Anaerobic } \\
\text { composting } \\
(\%)\end{array}$ & $\begin{array}{c}\text { Energy } \\
\text { recovery } \\
(\%)\end{array}$ & $\begin{array}{c}\text { Landfill } \\
(\%)\end{array}$ \\
\hline $\begin{array}{l}\text { Business as } \\
\text { Usual }\end{array}$ & 10 & 0 & 0 & 90 \\
\hline 1 & 20 & 0 & 40 & 40 \\
\hline 2 & 20 & 0 & 50 & 30 \\
\hline 3 & 20 & 10 & 50 & 20 \\
\hline 4 & 25 & 5 & 40 & 30 \\
\hline 5 & 30 & 10 & 35 & 25 \\
\hline 6 & 30 & 20 & 30 & 20 \\
\hline 7 & 30 & 20 & 40 & 10 \\
\hline 8 & 30 & 20 & 50 & 0 \\
\hline
\end{tabular}

Table 3: High level cost benefit analysis.

\begin{tabular}{|l|c|c|c|}
\hline Scenario & Cost Ranking & GWP Ranking & Overall Ranking \\
\hline Business as Usual & & & \\
\hline 1 & 1 & 7 & 7 \\
\hline 2 & 2 & 6 & 12 \\
\hline 3 & 5 & 5 & 25 \\
\hline 4 & 2 & 4 & 8 \\
\hline 5 & 4 & 3 & 12 \\
\hline 6 & 5 & 2 & 10 \\
\hline 7 & 7 & 1 & 7 \\
\hline 8 & 8 & - & - \\
\hline
\end{tabular}


Using the overall rankings as a guide the following scenarios were identified and taken forward for detailed Options Appraisal: Option 1 - lowest cost energy recovery option; Option 5 - best balance between cost and environmental impact; and Option 7 - lowest environmental impact option (measured as GWP).

It was ultimately decided to also include Scenario 8 in the detailed Options Appraisal.

\section{Options appraisal}

In order to carry out an options appraisal for each scenario it is necessary to consider how recycling, anaerobic composting and energy recovery will be undertaken. In the case study it was determined that recycling was best undertaken using source segregation as this approach could also provide the organic waste fraction for anaerobic composting using anaerobic digestion. As this process would take place outside the agreed system boundary for options appraisal this only left the energy recovery options for consideration.

In evaluating the energy recovery options a number of factors were considered including the amount of waste in each scenario that was destined for energy recovery. Given the quantities involved circa 1 million tonnes per annum the only energy recovery option proven to reliably process such tonnages is mass burn incineration. Large scale incineration can be undertaken using a choice of incineration technologies, namely moving grate and fluidised bed and both can be configured for either maximum electricity production or maximum recovery of energy in Combined Cooling, Heat and Power mode (CCHP) and therefore in the detailed Options Appraisal both these technology choices and operating configurations were considered for each scenario. For Scenario 8 the only energy recovery option considered capable of delivering zero waste to landfill was incineration coupled with plasma gasification on the basis that the process residues are vitrified as part of the process and that the vitrified material is then recycled in some form. Although not originally included as a technology choice it was decided to benchmark mass burn incineration against gasification technology using Scenario 5. This exercise produced a total of 14 options for appraisal using the Options Appraisal Model.

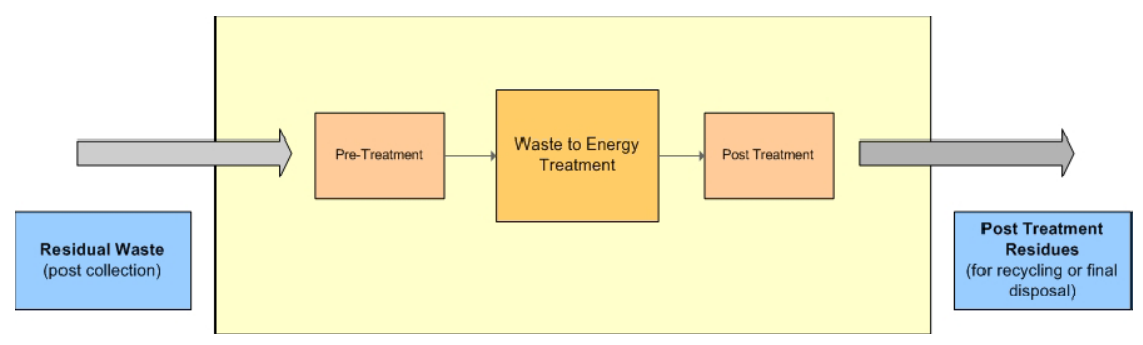

Figure 3: Case study system boundary. 
Table 4: $\quad$ Case study options for appraisal.

\begin{tabular}{|c|c|c|c|c|}
\hline Scenario & $\begin{array}{c}\text { Scenario } \\
\text { Parameters }\end{array}$ & Technology & Output & $\begin{array}{c}\text { MCA } \\
\text { Option }\end{array}$ \\
\hline $\begin{array}{l}\text { Business as } \\
\text { Usual }\end{array}$ & $\begin{array}{c}10 \% \text { recycling } \\
0 \% \text { anaerobic } \\
\text { digestion } \\
0 \% \text { energy } \\
\text { recovery } \\
90 \% \text { landfill }\end{array}$ & Not relevant & $\begin{array}{l}\text { Business as } \\
\text { Usual }\end{array}$ & $\begin{array}{c}\text { Business as } \\
\text { Usual }\end{array}$ \\
\hline 1 & $\begin{array}{l}15 \% \text { recycling } \\
0 \% \text { anaerobic } \\
\text { digestion } \\
40 \% \text { energy } \\
\text { recovery } \\
45 \% \text { landfill }\end{array}$ & $\begin{array}{l}\text { Moving Grate } \\
\text { Moving Grate } \\
\text { Fluidised Bed } \\
\text { Fluidised Bed }\end{array}$ & $\begin{array}{c}\text { Electricity } \\
\text { CCHP } \\
\text { Electricity } \\
\text { CCHP }\end{array}$ & $\begin{array}{l}1 \\
2 \\
3 \\
4\end{array}$ \\
\hline 5 & $\begin{array}{l}30 \% \text { recycling } \\
10 \% \text { anaerobic } \\
\text { digestion } \\
35 \% \text { energy } \\
\text { recovery } \\
25 \% \text { landfill }\end{array}$ & $\begin{array}{l}\text { Moving Grate } \\
\text { Moving Grate } \\
\text { Fluidised Bed } \\
\text { Fluidised Bed }\end{array}$ & $\begin{array}{c}\text { Electricity } \\
\text { CCHP } \\
\text { Electricity } \\
\text { CCHP }\end{array}$ & $\begin{array}{l}5 \\
6 \\
7 \\
8\end{array}$ \\
\hline 7 & $\begin{array}{c}30 \% \text { recycling } \\
20 \% \text { anaerobic } \\
\text { digestion } \\
40 \% \text { energy } \\
\text { recovery } \\
10 \% \text { landfill } \\
\end{array}$ & $\begin{array}{l}\text { Moving Grate } \\
\text { Moving Grate } \\
\text { Fluidised Bed } \\
\text { Fluidised Bed }\end{array}$ & $\begin{array}{c}\text { Electricity } \\
\text { CCHP } \\
\text { Electricity } \\
\text { CCHP }\end{array}$ & $\begin{array}{c}9 \\
10 \\
11 \\
12\end{array}$ \\
\hline 8 & $\begin{array}{c}30 \% \text { recycling } \\
20 \% \text { anaerobic } \\
\text { digestion } \\
50 \% \text { energy } \\
\text { recovery } \\
0 \% \text { landfill } \\
\end{array}$ & $\begin{array}{l}\text { Moving Grate } \\
\text { with plasma } \\
\text { gasification }\end{array}$ & $\begin{array}{l}\text { Maximum } \\
\text { landfill } \\
\text { diversion }\end{array}$ & 13 \\
\hline 5 & $\begin{array}{c}30 \% \text { recycling } \\
10 \% \text { anaerobic } \\
\text { digestion } \\
35 \% \text { energy } \\
\text { recovery } \\
25 \% \text { landfill } \\
\end{array}$ & Gasification & Electricity & 14 \\
\hline
\end{tabular}

The Options Appraisal Model helps identify those options with the best chance of realisation using sustainability based multi-criteria analysis (MCA). The criteria used in the Options Appraisal Model fall into four main categories: environmental; technical; financial and social. 
A number of project specific scoring sub-criteria are then determined. For the case study these were determined with the client and then their relative importance across the organisation was assessed by asking different parts of the organisation to weight both the main and sub-criteria. From this exercise an average weighting for each main and sub-criteria was determined and taken to reflect the general level of importance attached to that criterion by the organisation.

In addition to determining the weighting of each criterion the method of scoring each criterion also needs to be established and this will generally be a combination of derived quantitative data and qualitative assessment scores.

The Options Appraisal Model consists of a worksheet for each option into which the scores are input. This data is fed into the Raw Score Consolidation worksheet which calculates a relative ratio for the input data.

This relative ratio is then combined with the criterion weighting to produce a weighted score. The weighted scores are the added together to produce a cumulative score for each option with the cumulative scores brought together in the Results Report worksheet.

Table 5: $\quad$ Case study MCA assessment scores.

\begin{tabular}{|c|c|c|c|c|}
\hline Main Criteria & Sub-Criteria & Units & Weighting & $\begin{array}{l}\text { Scoring } \\
\text { Methodology }\end{array}$ \\
\hline Environmental & $\begin{array}{l}\text { Green House } \\
\text { Gas emissions } \\
\text { Net energy } \\
\text { generation } \\
\text { Land take }\end{array}$ & $\begin{array}{l}\mathrm{kg} \quad \mathrm{CO} 2- \\
\mathrm{eq} / \mathrm{t} \\
\mathrm{kWh} / \mathrm{t} \\
\mathrm{m} 2 / \mathrm{t}\end{array}$ & $\begin{array}{c}17.0 \\
12.0 \\
8.0\end{array}$ & $\begin{array}{l}\text { Quantitative } \\
\text { Quantitative } \\
\text { Quantitative }\end{array}$ \\
\hline Sub-Total & & & 37.0 & \\
\hline \multirow[t]{2}{*}{ Technical } & $\begin{array}{l}\text { Mass reduction } \\
\text { Modularity } \\
\text { Proveness }\end{array}$ & $\begin{array}{c}\% \\
\text { Score } \\
\text { Score } \\
\end{array}$ & $\begin{array}{c}12.0 \\
7.0 \\
8.0 \\
\end{array}$ & $\begin{array}{l}\text { Quantitative } \\
\text { Qualitative } \\
\text { Qualitative }\end{array}$ \\
\hline & & & 27.0 & \\
\hline \multirow[t]{2}{*}{ Financial } & $\begin{array}{l}\text { Capital } \\
\text { Expenditure } \\
\text { Operating } \\
\text { Expenditure }\end{array}$ & $\begin{array}{l}\text { Cost/tonne } \\
\text { Cost/tonne }\end{array}$ & $\begin{array}{l}9.4 \\
9.6\end{array}$ & $\begin{array}{l}\text { Quantitative } \\
\text { Quantitative }\end{array}$ \\
\hline & & & 19.0 & \\
\hline \multirow[t]{3}{*}{ Social } & Health impacts & $\begin{array}{l}\mathrm{kg} \mathrm{1,4-} \\
\mathrm{DCB} / \mathrm{t}\end{array}$ & 9.6 & Quantitative \\
\hline & $\begin{array}{l}\text { Community } \\
\text { acceptance and } \\
\text { local amenity }\end{array}$ & Score & 7.4 & Qualitative \\
\hline & & & 17.0 & \\
\hline
\end{tabular}




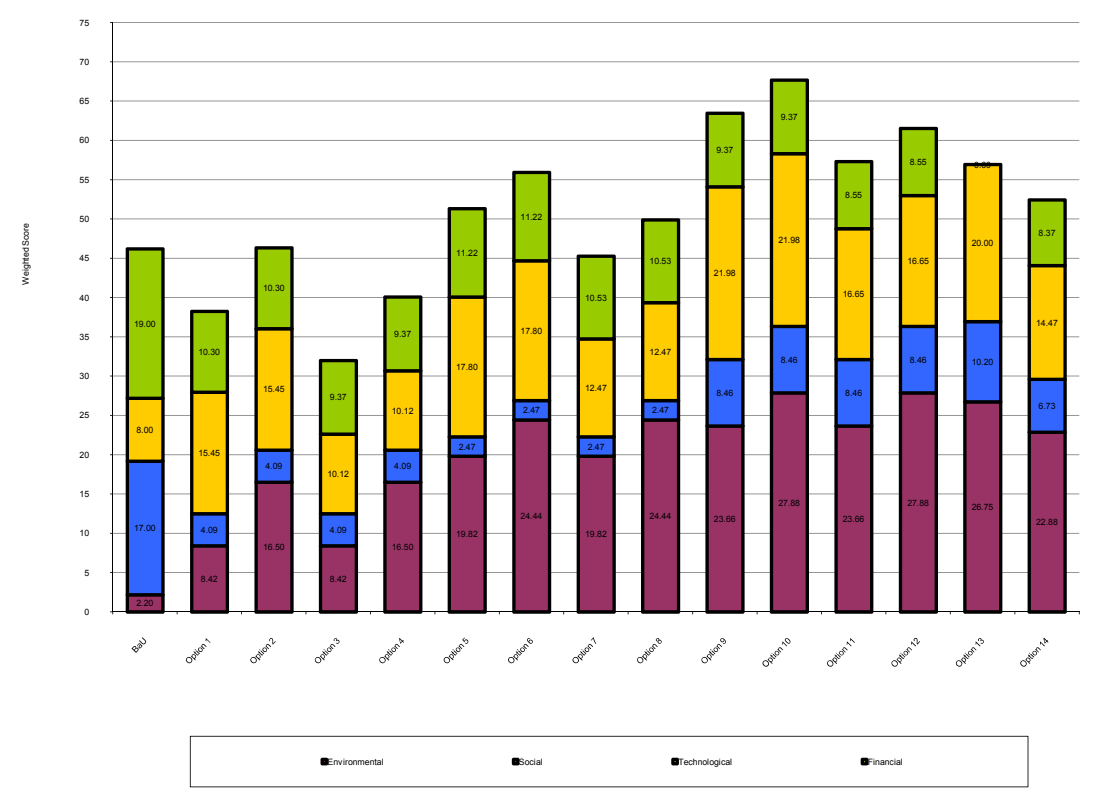

Figure 4: $\quad$ Case study MCA results.

\section{Discounted cashflow model}

Related to Options Appraisal is the development of a Discounted Cashflow (DCF) Model to provide detailed costing information for each option. The DCF Model is a key element in establishing the business case and uses data from the Waste Forecasting Model and Options Appraisal Model along with a series of base assumptions to calculate key financial data.

The base assumptions used in the DCF Model for the case study include: scenario parameters (Table 4); time variables including construction and commissioning phase and length of concession; indexation factors including waste growth; power generation assumptions; cost variables including capital and operating expenditure and revenue streams including energy and recyclate sales.

In order to determine actual estimated revenues the DCF Model - for each MCA option - firstly calculates the material and energy flows for that option using the scenario parameters and any waste growth indexation. The model also calculates, for each MCA option, the estimated capital and operating expenditure and, from the material and energy flows, the estimated operating revenues, All these results are then used within the model to calculate key financial data for each MCA option including: annual and discounted cashflows; Net Present Values and Internal Rate of Return.

This data is presented in tabular form with discounted cashflow also represented in graphical form. 


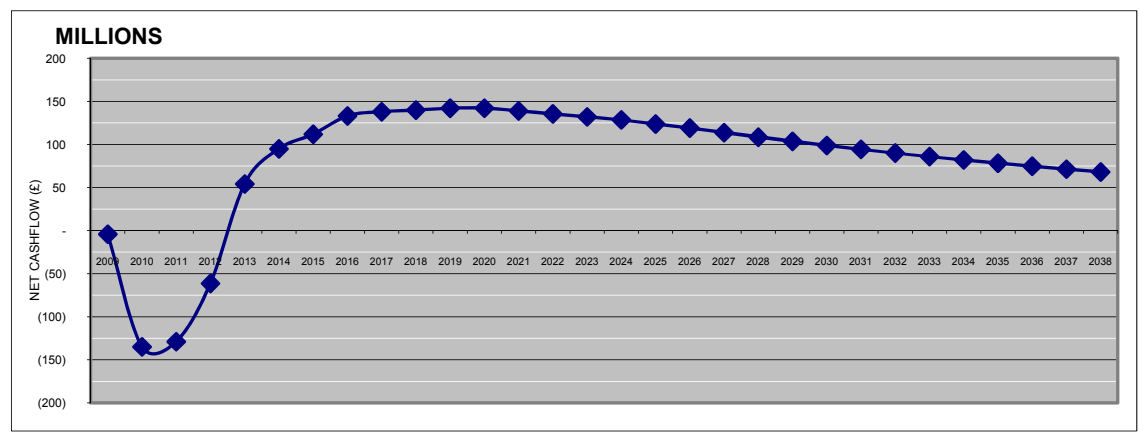

Figure 5: DCF model results.

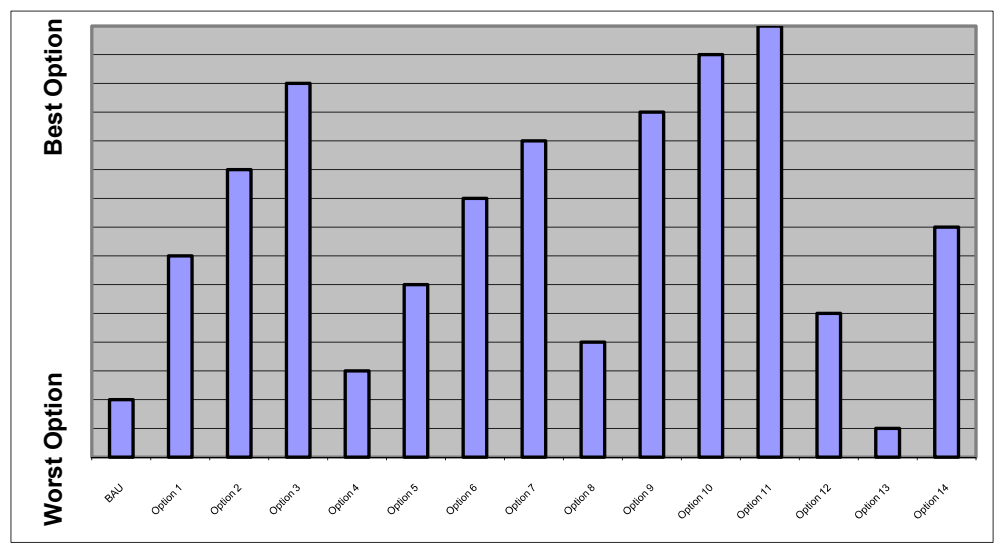

Figure 6: Case study DCF model summary data.

The estimated discounted cashflow and estimated Internal Rate of Return results for all the MCA options are then summarised with each option awarded a rating relative to the estimated discounted cashflow. The summary data is then presented as a discounted cashflow and as a rating.

\section{Results}

The case study Options Appraisal indicated that Scenario 7 with a 40\% energy recovery component using moving grate incineration technology operating in CCHP mode (MCA Option 10) was the option with the best chance of realisation. However, when detailed cost analysis is undertaken, whilst Scenario 7 still performs best the DCF Model indicates that a different choice of incineration technology and operating mode is preferred i.e. fluidised bed incineration technology operating in electricity only mode (MCA Option 11).

In practice this is as far as the case study progressed. The business case was never fully developed and no decision was made regarding the adoption of a waste-to-energy based waste management solution. What is clear from the case 
study results is that Scenario 7 consisting of a mix of $30 \%$ materials recycling; $20 \%$ anaerobic composting; 40\% energy recovery and 10\% landfill clearly outperforms all the other scenario choices. The choice of technology with regard to the energy recovery component is a more marginal decision, given that it is a choice between the first and second placed technologies. Moving grate incineration technology is better suited to the quantities involved and could be said to be the simpler of the two technologies. Fluidised bed incineration technology is potentially more efficient and offers better burn-out.

\section{Sensitivity analysis}

Sensitivity analysis is carried out at a number of stages throughout the options appraisal procedure.

For the Waste Forecasting Model sensitivity analysis should be carried out on the waste fractions that contribute most to the estimated total arisings. For the case study this was residential waste and sensitivity analysis was applied by amending the waste generation rate to a lower and higher per capita value.

The sensitivity analysis shows that changes in residential waste generation only begins to impact as full build out is approached with impact in both sensitivity tests being measured in ' 0,000 tonnes.

For the Options Appraisal Model sensitivity analysis was carried out on the criteria weightings used in the MCA. Two sets of alternative weightings were used including one set weighted entirely towards expenditure.

This sensitivity analysis showed that MCA Option 10 remained the preferred option under changing priorities. No sensitivity analysis in relation to the DCF Model was undertaken due to the case study being terminated. However, as with the Waste Forecasting Model and Options Appraisal Model a number of the assumptions used would have undergone sensitivity analysis as part of the formulation of the business case.

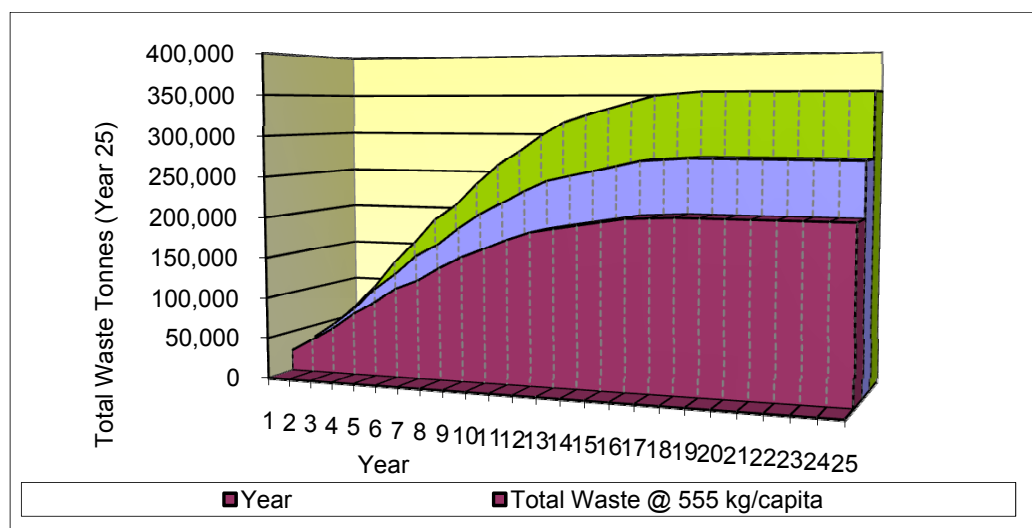

Figure 7: $\quad$ Per capita waste generation rate sensitivity analysis. 


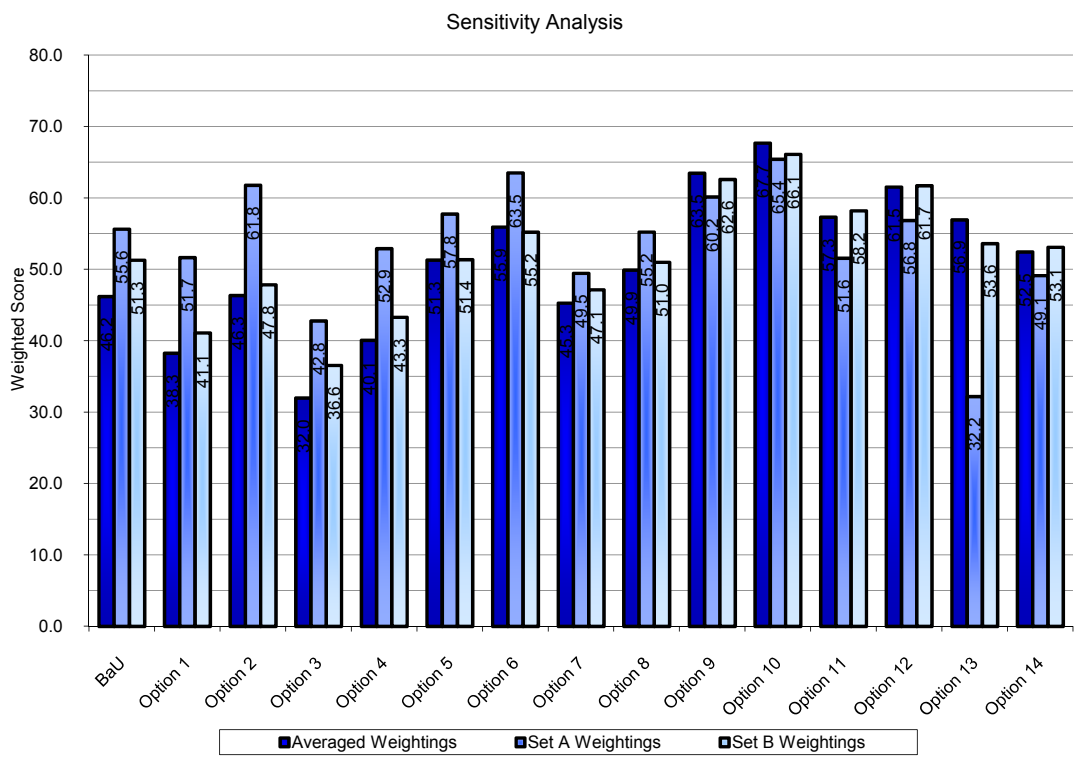

Figure 8: $\quad$ MCA criteria sensitivity analysis.

\section{Conclusions}

The appraisal of different waste management scenarios requires a structured approach and a number of different techniques. Using a structured approach allows 'gateway reviews' to be undertaken at various stages of the appraisal exercise. This enables options to be discarded when appropriate. It also allows for the continuing refinement of the remaining options.

Scenario modelling can include as many or as few scenarios as desired but must recognise the composition and quantity of the forecast waste arisings Scenarios taken forward for detailed options appraisal must be achievable under valid mass balance conditions.

Options appraisal needs to consider environmental, technical, financial and social impacts and the use of Multiple Criteria Analysis ensures the relative importance of these impacts to the client organisation is reflected in the appraisal.

In determining the costs of each option both indirect and direct expenditure and the phasing of this expenditure needs to be considered e.g. procurement as well as construction costs. Revenue streams need to reflect the components that make up the option e.g. electricity and heat sales for CHP configured energy recovery.

Sensitivity analysis should be undertaken to assist with the selection of the preferred option. It can be carried at various times during the appraisal exercise and should be focused on those factors which most influence the results. 
284 Waste Management and the Environment V

\section{References}

[1] British Standards Institute, BS5906: Waste Management in Building, Code of Practice, 2005

[2] Environment Agency, Waste and Resources Assessment Tool for the Environment (WRATE), 2010 